\title{
ASTROPHYSICS
}

DOI:http://dx.doi.org/10.18524/1810-4215.2020.33.216281

\section{PROBE OF THE MAGNETIC FIELD IN THE HOT SUPERGIANT $\zeta$ Per}

\author{
V.V. Butkovskaya ${ }^{1,2}$, S.I. Plachinda ${ }^{1,2}$ \\ ${ }^{1}$ Main Astronomical Observatory of National Academy of Sciences of Ukraine, \\ Kyiv, Ukraine,vbutkovskaja@gmail.com \\ ${ }^{2}$ Crimean Astrophysical Observatory, \\ Nauchny, Crimea
}

ABSTRACT. At the surface of $\sim 7 \%$ of single hot stars stable mainly dipolar strong magnetic fields have been detected. The main hypothesis today is that these magnetic fields are of fossil origin. In other words, these fields formed from the seed field in the molecular clouds from which the stars were formed. The recent observational and theoretical results confirm this theory: the properties of the observed fields correspond to those expected from fossil fields. Massive stars are stars whose initial mass exceeds about 8 solar masses. Massive stars play a significant role in the chemical and dynamical evolution of galaxies. However, much of their variability, particularly during their evolved supergiant stage, is poorly understood. To date magnetic field was registered only at three hot stars of I-II luminosity types: $\rho$ Leo $(\mathrm{B} 1 \mathrm{Ib}), \zeta$ Ori Aa (O9.2 Ib), and $\epsilon$ CMa (B1.5 II). We performed high-accuracy spectropolarimetric observation of the hot supergiant $\zeta$ Per (B1 Ib) over 26 nights from 1997 to 2012 with long-slit spectrograph mounted in the coude focus of $2.6-\mathrm{m}$ reflector ZTSh at the Crimean Astrophysical Observatory. We also used circularly polarized spectra obtained during 2 nights in 2008 with echelle spectrograph ESPADONS mounted at 3.6$\mathrm{m}$ CFHT. Effective magnetic field $B_{e}$ (longitudinal component of the field integrated over visible hemisphere) of $\zeta$ Per was calculated in the line He I 6678.149 A. Statistically significant longitudinal magnetic field $\left(B_{\mathrm{e}} / \sigma_{\mathrm{B}}>3\right)$ was registered in 14 from 199 single measurements. These significant magnetic field values are all in the range from -145 to $+148 \mathrm{G}$ with the mean error $27 \mathrm{G}$. We suppose the supergiant $\zeta$ Per can be magnetic, but its magnetic field properties is difficult to detect likely due to the insufficient precision of the used spectropolarimetric measurements compared to the expected field strength.

Key words: stars: early-type - stars: supergiants stars: magnetic fields - stars: individual ( $\zeta$ Per).

АНОТАЦЯ. На поверхні 7\% поодиноких гарячих зірок виявлені стабільні, переважно дипольні магнітні поля які сягають інколи десятків кілогаус.
Головною гіпотезою сьогодні є те, що ці магнітні поля мають реліктове походження. Іншими словами, ці поля утворились із поля в молекулярних хмарах, з яких утворилися зірки. Останні спостереження та результати теоретичного моделювання підтверджують цю теорію: властивості глобальних полів що спостерігаються, відповідають тим, що мали б очікуватись у реліктових магнітних полів. Масивні зірки - це ті зірки, початкові маси яких приблизно у 8 і більше разів перевищують масу Сонця. Вони відіграють значну роль у хімічному та динамічному розвитку галактик. Однак їх змінність, особливо під час еволюційної стадії надгігантів, недостатньо вивчена. На сьогоднішній день магнітне поле було зареєстровано лише у трьох гарячих зірок I-II типів світності: $\rho$ Leo (B1 Ib), $\zeta$ Ori Aa (O9.2 Ib) i $\epsilon$ CMa (B1.5 II). У цій роботі ми провели високоточне спектрополяриметричне дослідження гарячого надгіганта $\zeta$ Per (B1 Ib). Спостереження були виконані протягом 26 ночей з 1997 по 2012 pp. за допомогою класичного спектрографа, встановленого у фокусі куде 2,6-метрового рефлектора ЗТШ в Кримській астрофізичній обсерваторії. Ми також використали циркулярно поляризовані спектри, отримані протягом 2 ночей в 2008 році за допомогою ешеле-спектрографа ESPADONS, встановленого на 3,6 м Канада-Франко-Гавайському телескопі (СFHТ). Ефективне магнітне поле $B_{e}$ (поздовжня складова поля, інтегрована по видимій півкулі) $\zeta$ Per було розраховано по лінії Не I $6678.149 \AA$ А. Статистично значуще поздовжне магнітне поле $\left(B_{\mathrm{e}} / \sigma_{\mathrm{B}}>3\right)$ було зареєстровано в 14 із 199 одиничних вимірювань. Усі ці значущі значення магнітного поля знаходяться в діапазоні від -145 до +148 гаусів зі середньою похибкою у 27 гаусів. На цій підставі ми припускаємо, що надгігант $\zeta$ Per має магнітне поле, але характер змінності якого по наявному матеріалу спостережень важко виявити через недостатню точність наших спектрополяриметричних вимірювань порівняно з очікуваною напруженістю поля. 
Ключові слова: зірки ранніх спектральних класів, надгіганти, масивні зірки, гарячі зірки, магнітні поля зірок.

\section{Introduction}

At the surface of $\sim 7 \%$ of single hot stars stable mainly dipolar magnetic fields have been detected. The main hypothesis today is that these magnetic fields are of fossil origin. In other words, these fields formed from the seed field in the molecular clouds from which the stars were formed. The recent observational and theoretical results confirm this theory: the properties of the observed fields correspond to those expected from fossil fields.

Massive stars are stars whose initial mass exceeds about 8 solar masses. These stars play a significant role in the chemical and dynamical evolution of galaxies. However, much of their variability, particularly during their evolved supergiant stage, is poorly understood.

To date only three hot supergiants have been found to host a magnetic field. Kholtygin et al. (2007) reported the possible detection of the magnetic field with polar strength $240 \pm 50 \mathrm{G}$ on $\rho$ Leo (B1 Ib). Bouret et al. (2008) reported the detection of a weak magnetic field of 50-100 G on the supergiant $\zeta$ Ori Aa (O9.2 Ib). The result was confirmed by Blazere et al. (2015). Fossati et al. (2015) detected the magnetic field with polar strength of at least $13 \mathrm{G}$ on the bright giant $\epsilon$ CMa (B1.5 II).

$\zeta$ Per (HD 24398, HR 1203, B1 Ib) is a hot supergiant, which main stellar parameters are shown in Table 1. We present here the results of magnetic field measurements on $\zeta$ Per.

Table 1: Stellar parameters of $\zeta$ Per.

\begin{tabular}{lrl}
\hline Parameter & Value & Reference \\
\hline Sp. Type & B1 Ib & Lesh (1968) \\
$V$ & 2.85 & SIMBAD \\
$T_{\text {eff }}(\mathrm{K})$ & 22040 & Zorec et al. (2009) \\
$\log g$ & 3.061 & Huang \& Gies $(2008)$ \\
$v \sin i(\mathrm{~km} / \mathrm{s})$ & 45 & Simón-Díaz et al. (2017) \\
$M / M_{\odot}$ & 15.5 & Tetzlaff et al. (2011) \\
$R / R_{\odot}$ & 26 & P. Fracassini et al. (2001) \\
$L / L_{\odot}$ & 47039 & Hohle et al. (2010) \\
$t(\mathrm{Myr})$ & 12.6 & Tetzlaff et al. (2011) \\
\hline
\end{tabular}

\section{Observations}

Spectropolarimetric observations of $\zeta$ Per were carried out with the long-slit spectrograph and the circular polarization analyzer mounted in the cóude focus of the 2.6-m reflector ZTSh at the Crimean Astrophysical Observatory (26 nights from 1997 to 2012, spectral resolution $R \sim 30000)$. We also used polarimetric

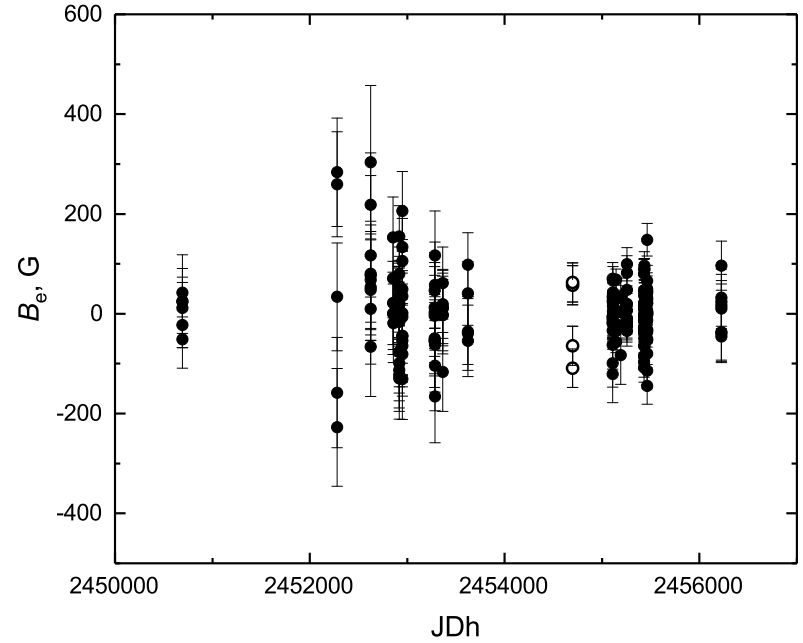

Figure 1: Magnetic field of $\zeta$ Per measured in 1997 - 2012. Filled circles indicate data obtained at ZTSh (CrAO), open circles - data obtained at ESPADONS (CFHT).

data collected during 2 nights in 2008 with the echelle spectrograph ESPADONS (spectral resolution $R \sim$ 65000) mounted at the 3.6-m CFHT (Hawaii, USA). Effective magnetic field $B_{e}$ (longitudinal component of the field integrated over visible hemisphere) of $\zeta$ Per was calculated in the line He I 6678.149 $\AA$ (effective Lande factor $z=1$ ) with the procedure discussed in detail by Butkovskaya \& Plachinda (2007).

\section{Results}

In Figure 1 individual magnetic field $\left(B_{\mathrm{e}}\right)$ measurements $(N=199)$ of $\zeta$ Per are presented. Statistics on the magnetic field measurement is illustrated in Figure 2. Most $B_{e}$ values fall in the range from -50 to $+50 \mathrm{G}$, and the mean value $\left\langle B_{\mathrm{e}}\right\rangle=$ $2.6 \pm 5.2 \mathrm{G}$. The mean error of a single measurement, $<\sigma_{\mathrm{B}}>=52 \mathrm{G}$, while the minimum error is $19 \mathrm{G}$. Statistically significant longitudinal magnetic field $\left(B_{\mathrm{e}} / \sigma_{\mathrm{B}}>3\right)$ was registered in 14 single measurements. These significant magnetic field values are all in the range from -145 to $+148 \mathrm{G}$ with mean error $27 \mathrm{G}$.

\section{Conclusion}

We suppose the supergiant $\zeta$ Per can be magnetic, but its magnetic field properties is difficult to detect likely due to the insufficient precision of the used spectropolarimetric measurements compared to the expected field strength. 

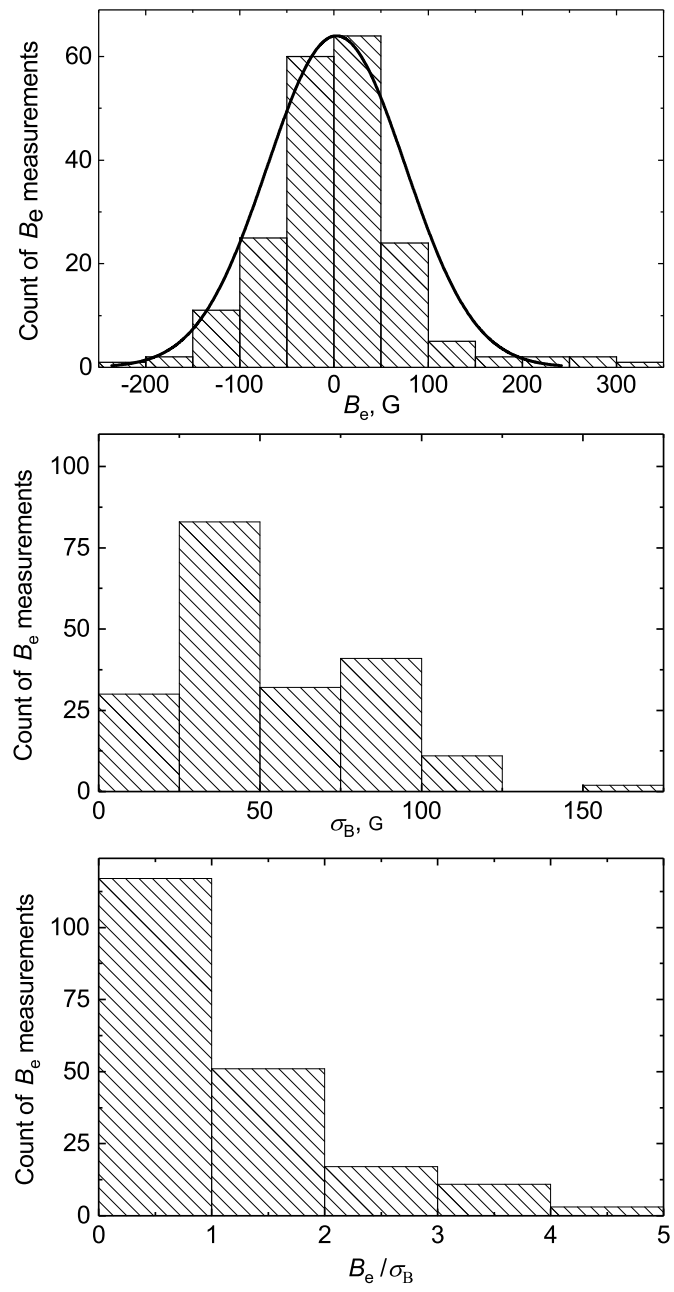

Figure 2: Distribution of the magnetic field $B_{\mathrm{e}}$ (top panel), its errors $\sigma_{\mathrm{B}}$ (middle panel) and signal-to-noise ratio $B_{\mathrm{e}} / \sigma_{\mathrm{B}}$ (bottom panel). Normal distribution curve is shown on the top panel by the strong line.

Acknowledgements. This study particularly based on observations obtained at the Canada-France-Hawaii Telescope (CFHT). This research used the facilities of the Canadian Astronomy Data Centre operated by the National Research Council of Canada with the support of the Canadian Space Agency.

\section{References}

Blazère, A., Neiner, C., Tkachenko, A., et al.: 2015, Astron. Astrophys., 582, A110.

Bouret, J.-C., Donati, J.-F., Martins, F., et al.: 2008, MNRAS, 389, 75.

Butkovskaya, V. V. \& Plachinda, S. I.: 2007, Astron. Astrophys., 469, 1069.

Hohle, M. M., Neuhäuser, R., Schutz, B. F.: 2010, Astron. Nachr., 331, 349.

Huang, W. \& Gies, D.R.: 2008, ApJ, 683, 1045.

Fossati, L., Castro, N., Morel, T., et al.: 2015, Astron. Astrophys., 574, A20.

Kholtygin A.F., Chountonov G.A., Fabrika S.N. et al.: 2007, Physics of Magnetic Stars, 262.

Lesh, J.R.: 1968, ApJSS, No. 151, 16, 371.

McErlean, N.D., Lennon, D.J., Dufton, P.L.: 1999, Astron. Astrophys., 349, 553.

Pasinetti Fracassini, L. E., Pastori, L., Covino, S., Pozzi, A.: 2001, Astron. Astrophys., 367, 521.

Simón-Díaz, S., Godart, M., Castro, N., et al.: 2017, Astron. Astrophys., 597, A22.

Tetzlaff, N., Neuhäuser, R., Hohle, M. M.: 2011, MNRAS, 410, 190.

Zorec, J., Cidale, L., Arias, M. L., et al., 2009, Astron. Astrophys., 501, 297. 